\title{
ANALISIS PENGARUH SUKU BUNGA DAN NILAI KURS TERHADAP TINGKAT INFLASI DI INDONESIA
}

\author{
Muslihul Umam \& Isabela \\ STAI Nazhatut Thullab Sampang \\ Email: muslehumam@gmail.com
}

\begin{abstract}
Abstrak
Inflasi merupakan salah satu indikator perekonomian yang penting, laju perubahannya selalu diupayakan rendah dan stabil. Inflasi yang tinggi dan tidak stabil merupakan cerminan akan kecenderungan naiknya tingkat harga barang dan jasa secara umum dan terus menerus sehingga akan melemahkan daya beli masyrakat yang nantinya akan berdampak pada penurunan pendapatan nasional. Oleh karena itu diharapkan adanya pengendalian laju inflasi yang akhir-akhir ini menunjukkan grafik yang meningkat. Penelitian ini membahas tentang "Analisis Pengaruh Suku bunga dan Nilai Kurs Terhadap Tingkat Inflasi Di Indonesia Periode 1985-2014", bertujuan untuk mengetahui pengaruh suku bunga, dan nilai kurs terhadap tingkat inflasi di Indonesia dengan menggunakan error correction model (ECM). Hasil penelitian ini menunjukkan bahwa suku bunga berpengaruh positif dan signifikan terhadap tingkat inflasi di Indonesia, nilai kurs RP/US Dollar berpengaruh positif dan signifikan terhadap tingkat inflasi di Indonesia.
\end{abstract}

Keywords: tingkat inflasi, suku bunga, dan nilai kurs.

\begin{abstract}
Inflation is one of the important economic indicators, the rate of change is always besought low and stable. High and unstable inflation is a reflection of the tendency to increase the level of prices of goods and services in general and continuously so that it will weaken the purchasing power of the people which will reduce national incomelater. Therefore, it is expected to control the inflation rate, which lately shows an increasing graph. This study discusses "The analysis of the Influence of Interest Rates and Exchange Rates to the Inflation Rate in Indonesia for the Period 1985-2014", aims to determine the effect of interest rates, and the exchange rate on the inflation rate in Indonesia using the error correction model (ECM). The results of this study indicate that interest rates have a positive and significant effect on the inflation rate in Indonesia, the exchange rate of Rupiah / US dollar has a positive and significant effect on the inflation rate in Indonesia.
\end{abstract}

Keywords: Inflation Rate, Interest Rates, and Exchange Rates. 


\section{Pendahuluan}

Negara berkembang umumnya cenderung masih sangat rentan dengan adanya goncangan terhadap kestabilan kegiatan perekonomian. Di Negara seperti Indonesia seringkali terjadi gejolak dalam hal menjaga kestabilan kegiatan perekonomian. Perekonomian selalu menjadi perhatian yang paling penting dikarenakan apabila perekonomian dalam kondisi tidak stabil maka akan timbul masalah-masalah ekonomi seperti rendahnya pertumbuhan ekonomi, tingginya tingkat pengangguran dan tingginya tingkat inflasi. Ukuran kestabilan perekonomian yakni dimana terjadi pertumbuhan ekonomi, tidak terdapat angka pengangguran yang tinggi serta tingkat harga barang dan jasa yang perubahannya tidak terlalu berarti yang tercermin dari laju inflasi.

Inflasi merupakan salah satu indikator perekonomian yang penting, laju perubahannya selalu di upayakan rendah dan stabil agar tidak menimbulkan penyakit makro ekonomi yang nantinya akan memberikan dampak ketidakstabilan dalam perekonomian. Inflasi yang tinggi dan tidak stabil merupakan naiknya tingkat harga barang dan jasa secara umum dan terus menerus selama periode waktu tertentu. Dengan naiknya tingkat harga ini daya beli dari masyarakat akan menurun akibatnya barang-barang hasil produksi tidak akan habis terjual dan produsen pun tidak akan menambah besaran investasinya. Apabila besaran investasi berkurang hal ini akan menyebabkan pendapatan nasional akan menurun, yang merupakan gambaran dari pertumbuhan ekonomi yang pada akhirnya akan mempengaruhi kestabilan kegiatan suatu perekonomian.

Tabel 1. Perkembangan Tingkat Inflasi

di Indonesia Periode 2005 - 2012

\begin{tabular}{|c|c|}
\hline Tahun & Inflasi (\%) \\
\hline 2005 & 17.11 \\
\hline 2006 & 6.6 \\
\hline 2007 & 6.59 \\
\hline 2008 & 11.06 \\
\hline 2009 & 2.78 \\
\hline 2010 & 6.96 \\
\hline 2011 & 3.79 \\
\hline 2012 & 4.3 \\
\hline
\end{tabular}

Sumber: Badan Pusat Statistik, 2016

Berdasarkan Tabel 1. dapat dilihat perkembangan inflasi selama periode 2005 sampai 2012 mengalami fluktuasi, inflasi tertinggi terjadi pada periode 2005 sebesar $17.11 \%$ kemudian bergerak turun pada periode 2006 sebesar $6.6 \%$ setelah itu naik kembali pada tahun 2008 yaitu sebesar $11.06 \%$ dikarenakan pada saat itu terjada krisis global yang melanda dunia sehingga berdampak buruk bagi perekonomian di Indonesia. Selama periode 2005-2012 inflasi terendah pada periode 2009 yaitu sebesar $2.78 \%$ namun kemudian mengalami kenaikan pada periode 2010 yaitu sebesar 6.69\% dan kemudian mengalami penurunan pada periode 2011 sebesar $3.79 \%$ hingga kemudian mengalami kenaikan pada periode 2012 sebesar $4.3 \%$. 
Krisis moneter yang terjadi pada tahun 1998 telah membuat perekonomian Indonesia menjadi tidak stabil dikarenakan adanya kenaikan inflasi. Kenaikan inflasi telah meningkat hingga mencapai $77.63 \%$ pada saat itu. Inflasi di Indonesia dipicu oleh kenaikan harga komoditi impor (imported inflation) dan membengkaknya hutang luar negeri akibat dari terdepresiasinya nilai tukar rupiah terhadap dolar Amerika dan mata uang asing lainnya. ${ }^{1}$ Akibatnya, untuk mengendalikan tekanan inflasi, maka terlebih dahulu harus dilakukan penstabilan nilai tukar rupiah terhadap valuta asing, khususnya dolar Amerika.

Ketidakstabilan nilai tukar akan mempengaruhi arus modal atau investasi dan perdagangan Internasional. Indonesia sebagai negara yang banyak mengimpor bahan baku industri mengalami dampak dari ketidakstabilan kurs, yang dapat dilihat dari rnelonjaknya biaya produksi sehingga menyebabkan harga barangbarang milik Indonesia mengalami kenaikan. Dengan melemahnya rupiah menyebabkan perekonomian Indonesia menjadi goyah dan dilanda krisis ekonomi dan kepercayaan terhadap mata uang dalam negeri. ${ }^{2}$ Dengan adanya lonjakanlonjakan drastis pada tingkat kurs tersebut akan membuat para produsen kesulitan untuk mendapatkan bahan baku dan barang modal yang mempunyai kandungan impor yang tinggi sehingga kemudian akan berdampak pada naiknya biaya untuk mengimpor barang untuk keperluan proses produksi sehingga akan mempengaruhi tingkat harga domestik yang merupakan cerminan dari tingkat inflasi.

Sebuah penelitian menganalisis pengaruh variabel-variabel SBI rate, output gap, produktivitas, nilai tukar dan inflasi luar negeri terhadap tingkat inflasi dalam negeri dengan menggunakan Error Correction Model (ECM). Hasilnya menunjukkan, selama periode nilai tukar mengambang, dalam jangka panjang instrument kebijakan moneter (SBI rate), output gap dan nilai tukar mempunyai pengaruh yang signifikan terhadap inflasi Indonesia. ${ }^{3}$

Karena pengaruh tingkat inflasi yang cukup signifikan terhadap perekonomian suatu negara, maka perubahan tingkat inflasi di Indonesia perlu mendapat perhatian dari pemerintah agar kestabilan ekonomi tetap terjaga. Penelitian ini menggunakan Error Correction Model (ECM), untuk menganalisis hubungan kausalitas dari variabel yang sedang diuji, baik dalam jangka panjang maupun jangka pendek. Variabel yang digunakan adalah inflasi sebagai variabel yang diteliti serta variabel suku bunga dan nilai kurs sebagai variabel penduga dengan judul penelitian "Analisis Pengaruh Suku Bunga Dan Nilai Kurs Terhadap Tingkat Inflasi Di Indonesia".

\footnotetext{
${ }^{1}$ Atmadja S.A, Inflasi indonesia :"Sumber sumber Penyebab Dan pengendaliannya" Jurnal Akuntansi dan Keuangan, Universitas Kristen Petra, Vol. 1 No. 1, Mei 1999.

2 Triyono, "Analisis PerubahanKurs Rupiah Terhadap Dollar Amerika” Jurnal Ekonomi

Pembangunan, Vol 9, No.2, Desember 2008, hal 156-167.

3 Endri, "Analisis Faktor- Faktor Yang mempengaruhi Inflasi Jangka Pendek di Indonesia". Jurnal

Ekonomi Pembangunan Kajian Negara Ekonomi Negara Berkembang, Hal: 1-13 2008.
} 
Tabel 2. Penelitian Terdahulu

\begin{tabular}{|l|l|l|}
\hline \multicolumn{1}{|c|}{$\begin{array}{c}\text { Nama } \\
\text { Peneliti }\end{array}$} & \multicolumn{1}{|c|}{ Variabel } & \multicolumn{1}{c|}{ Hasil Penelitian } \\
\hline $\begin{array}{l}\text { Langi, et. al } \\
\text { 2014) }\end{array}$ & $\begin{array}{l}\text { Variabel Dependen: } \\
\text { Inflasi } \\
\begin{array}{l}\text { Variabel Independen: } \\
\text { Suku bunga BI, jumlah } \\
\text { uang beredar, tingkat } \\
\text { kurs }\end{array}\end{array}$ & $\begin{array}{l}\text { Hasil penelitian ini menunjukkan bahwa } \\
\text { suku bunga BI berpengaruh positif dan } \\
\text { signifikan terhadap tingkat inflasi di } \\
\text { Indonesia. Sedangkan jumlah uang } \\
\text { beredar dan tingkat kurs Rp/Us dollar } \\
\text { berpengaruh positif dan tidak signifikan } \\
\text { terhadap tingkat inflasi di Indonesia. }\end{array}$ \\
\hline $\begin{array}{l}\text { Rangkuti } \\
(2007)\end{array}$ & $\begin{array}{l}\text { Variabel Dependen: } \\
\text { Vang kartal }\end{array}$ & $\begin{array}{l}\text { Hasil penelitian menunjukkan bahwa } \\
\text { Suku bunga BI berpengaruh positif dan } \\
\text { sendapnifikan terhadap tingkat inflasi di } \\
\text { tukar, suku bunga }\end{array}$ \\
& $\begin{array}{l}\text { Indonesia. Jumlah uang beredar dan } \\
\text { tingkat kurs Rp/Us dollar berpengaruh } \\
\text { positif dan tidak signifikan terhadap } \\
\text { tingkat inflasi di Indonesia. }\end{array}$ \\
\hline
\end{tabular}

\section{Kajian Pustaka}

Faktor-faktor yang menimbulkan inflasi adalah : Inflasi tarikan permintaan, inflasi tarikan permintaan terjadi apabila sektor perusahaan tidak mampu dengan cepat melayani permintaan masyarakat dalam pasaran. ${ }^{4}$ Masalah kekurangan barang akan berlaku dan ini akan mendorong kepada kenaikan harga-harga, inflasi tarikan permintaan biasanya berlaku ketika perekonomian mencapai tingkat pengangguran tenaga kerja penuh dan pertumbuhan ekonomi berjalan pesat. Inflasi desakan biaya, inflasi desakan biaya adalah masalah kanaikan harga-harga dalam perekonomian yang diakibatkan oleh kenaikan biaya produksi. ${ }^{5}$

Variabel suku bunga berpengaruh terhadap besaran tingkat inflasi, tingkat bunga yang meningkat akan mengurangi investasi. Untuk menghindari kemerosotan nilai modal yang mereka pinjamkan, instiusi keuangan akan menaikkan tingkat bunga ke atas pinjaman-pinjaman mereka. Makin tinggi tingkat inflasi, makin tinggi pula tingkat bunga yang mereka tentukan. Tingkat bunga yang tinggi akan mengurangi kegairahan penanam modal untuk mengembangkan sektor-sektor yang produktif. ${ }^{6}$ Selain itu terdapat efek Fisher yakni efek ekspektasi inflasi terhadap suku bunga nominal.

Faktor lain yang berpengaruh terhadap laju inflasi adalah nilai kurs. Depresiasi (penurunan) nilai tukar riil domestik berarti bahwa barang-barang domestik menjadi lebih murah dibandingkan dengan barang-barang negara asing. Perubahan ini mendorong konsumen dalam negeri dan luar negeri untuk membeli lebih banyak barang domestik dan membeli lebih sedikit barang dari negara lain. Hasilnya, ekspor meningkat dan impor menurun. Apresiasi (peningkatan) nilai

\footnotetext{
${ }^{4}$ Sukirno, Sadono, Pengantar Teori Makro Ekonomi Edisi Kedua, (Jakarta: PT Raja Grafindo Persada, 1999).

5 Ibid

${ }^{6}$ Ibid
} 
tukar riil domestik berarti bahwa barang domestik menjadi lebih mahal dibandingkan dengan barang luar negeri sehingga ekspor neto menurun. ${ }^{7}$

\section{Metodologi Penelitian}

Jenis dan Sumber Data

Penelitian ini dibatasi dengan menganalisis data sekunder kuantitatif pada rentang waktu antara tahun 1985 - 2014 dengan pertimbangan ketersediaan data. Penelitian ini secara keseluruhan menggunakan data sekunder time series. Sumber data berasal dari berbagai sumber, antara lain Statistik Indonesia terbitan Badan Pusat Statistik, Statistik Ekonomi dan Keuangan Indonesia, Laporan Kebijakan Moneter terbitan Bank Indonesia.

\section{Analisa Data}

Dalam penelitian ini menggunakan metode error correction model (ECM) sebagai alat ekonometrika perhitungan dan analisis deskriptif untuk mengidentifikasi hubungan jangka panjang dan jangka pendek yang terjadi karena adanya kointegrasi antar variabel penelitian. Dengan model ECM:

$$
\mathrm{D}(\mathrm{Y})=\mathrm{b}_{0}+\mathrm{b}_{1} \mathrm{D}\left(\mathrm{X}_{1}\right)+\mathrm{b}_{2} \mathrm{D}\left(\mathrm{X}_{2}\right)+\mathrm{ECT}(-1)+\mathrm{e}
$$

Dimana:

$$
\begin{array}{ll}
\mathrm{Y} & \text { : Tingkat inflasi (\%) } \\
\mathrm{X}_{1} & \text { : Suku bunga (\%) } \\
\mathrm{X}_{2} & \text { : Nilai kurs (Rp/ Us dollar) }
\end{array}
$$

\section{Hasil dan Pembahasan}

Tabel 3. Hasil Uji Asumsi Klasik

\begin{tabular}{|l|c|}
\hline \multicolumn{1}{|c|}{ Uraian/ Variabel } & Sig. \\
\hline Jarque-Bera Prob & 0.820810 \\
\hline Obs ${ }^{*}$ R-squared & 0.5244 \\
\hline F statistic RESID & 0.3396 \\
\hline F statistic & 0.4185 \\
\hline R-squared inflasi & 0.739424 \\
\hline R-squared suku bunga & 0.198676 \\
\hline
\end{tabular}

Berdasarkan uji normalitas dapat diketahui bahwa p-value (jarque-berra) sebesar $0.820810>\alpha=10 \%$. Maka dapat disimpulkan bahwa data yang digunakan dalam model ECM berdistribusi normal. Data jangka pendek diperoleh bahwa nilai Obs*R-squared adalah $0.5244>\alpha=5 \%$, dapat disimpulkan bahwa dalam model tidak terdapat masalah heterokedastisitas. Probabilitas F statistic RESID $0.3396>$ 0.05 , maka hipotesis yang menyatakan bahwa model bebas dari masalah serial korelasi diterima. Probabilitas F statistic $0.4185>0.05$, maka hipotesis bahwa model linear adalah diterima. Pada uji multikolinearitas $\mathrm{R}^{2}{ }_{1}>\mathrm{R}^{2}{ }_{2}$ menunjukan bahwa dalam model tidak ditemukan adanya multikolinearitas, dengan formulasi:

Inflasi $=\mathrm{a}_{0}+\mathrm{a}_{1}$ interest $+\mathrm{a}_{2}$ kurs

Interest $=\mathrm{a}_{0}+\mathrm{a}_{1}$ kurs

Untuk persamaan 1 nilai $\mathrm{R}^{2}$ adalah sebesar $0.739424\left(\mathrm{R}^{2} 1\right)$

Untuk persamaan 2 nilai $\mathrm{R}^{2}$ adalah sebesar $0.198676\left(\mathrm{R}^{2} 2\right)$

7 Mankiw, N. Gregory, Pengantar Ekonomi Makro Edisi Asia Volume 2, Jakarta: Salemba Empat, 2013) 
Tabel 4. Hasil Uji Stasionaritas dan Kointegrasi

\begin{tabular}{|l|c|c|}
\hline Variabel & t-statistic & Prob \\
\hline Inflation & -8.884369 & 0.0000 \\
\hline Interest & -6.262441 & 0.0000 \\
\hline Kurs & -6.384504 & 0.0000 \\
\hline ECT & -3.982312 & 0.0048 \\
\hline
\end{tabular}

Data Inflasi, Interest Rate dan Kurs pada $1^{\text {st }}$ Difference sudah stationer karena t hitung statistic < dari prob 0.01. Setelah dilakukan pengujian DF untuk menguji residual yang dihasilkan, didapatkan bahwa residual stasioner pada data level yang terlihat dari nilai t-statistik yang signifikan pada nilai kritis 5\% (prob 0.0048). Dengan demikian dapat dikatakan bahwa data tersebut terkointegrasi.

Di dapat ADF hitung untuk residual persamaan kointegrasi (signifikan) pada signifikansi $1 \%$. Kondisi tersebut menyimpulkan bahwa variabel-variabel yang diamati dalam penelitian ini berkointegrasi pada derajat yang sama. Hal ini menunjukan adanya hubungan jangka panjang antara semua variabel independen dengan variabel dependen. Dengan kata lain, suku bunga, kurs (nilai kurs) mempunyai hubungan jangka panjang dengan tingkat inflasi.

Tabel 5. Hasil Uji Statistik ECM

\begin{tabular}{|l|c|}
\hline \multicolumn{1}{|c|}{ Variabel } & Koefisien \\
\hline $\mathrm{R}^{2}$ & 0.873155 \\
\hline Durbin-Watson & 1.817140 \\
\hline \multirow{3}{*}{ Konstanta } & 0.5822 \\
& $(-$ \\
& $0.735736)$ \\
\hline \multirow{2}{*}{ Suku bunga } & $0.0000^{* * *}$ \\
& $(1.678432)$ \\
\hline \multirow{2}{*}{ Nilai kurs } & $0.0046^{* * *}$ \\
& $(0.003727)$ \\
\multirow{2}{*}{ ECT (-1) } & $0.0008^{* * *}$ \\
& $(-$ \\
\end{tabular}

Keterangan:

Error

Variabel dependent: D(Inflasi); ( ) Menunjukkan koefisien Standar

${ }^{*}$ Signifikan pada level 10\%; ** Signifikan pada level 5\%; ${ }^{* * *}$ Signifikan pada level $1 \%$

Model regresi:

$\mathrm{D}$ (inflation) $=\mathrm{b}_{0}+\mathrm{b}_{1} \mathrm{D}($ interest $)+\mathrm{b}_{2} \mathrm{D}($ kurs $)+\mathrm{ECT}(-1)+\mathrm{e}$

$\mathrm{D}$ (inflation) $=-0.735736+1.678432 * \mathrm{D}$ (interest) $+0.003727 * \mathrm{D}$ (kurs) $0.720997 *$ ECT(-1)

Model diatas menunjukkan bahwa nilai koefisien ECT pada model tersebut signifikan dan bertanda negatif untuk estimasi inflation. Hasil estimasi ECM di atas memperlihatkan bahwa dalam jangka pendek maupun jangka panjang variabel yang digunakan dalam kajian ini berpengaruh secara signifikan terhadap inflasi. Dengan nilai $\mathrm{R}^{2}$ sebesar sekitar 0.873155 atau $87,32 \%$ dapat dikatakan bahwa jenis variabel bebas yang dimasukkan dalam model sudah cukup baik, sebab hanya 
sekitar $12,68 \%$ keragaman variabel terikat yang dipengaruhi oleh variabel bebas di luar model.

Hasil estimasi diatas menggambarkan bahwa dalam jangka pendek perubahan tingkat suku bunga dan kurs mempunyai pengaruh yang positif terhadap inflasi, cetiris paribus.

Berdasarkan persamaan jangka pendek tersebut dengan menggunakan metode ECM menghasilkan koefisien ECT. Koefisien ini mengukur respon regressand setiap periode yang menyimpang dari keseimbangan. Koefisien koreksi ketidakseimbangan ECT dalam bentuk nilai absolute menjelaskan seberapa cepat waktu diperlukan untuk mendapat nilai keseimbangan. Nilai koefisien ECT sebesar 0.720997 mempunyai makna bahwa perbedaan antara tingkat inflasi dengan nilai keseimbangannya sebesar 0.720997 yang akan disesuaikan dalam waktu 1 tahun.

\section{Pembahasan}

Pengaruh perubahan suku bunga terhadap perubahan tingkat inflasi di Indonesia. Dari hasil perhitungan menunjukkan bahwa perubahan persentase suku bunga dalam jangka pendek (DSukubunga) mempunyai hubungan yang positif dan signifikan terhadap perubahan persentase Tingkat inflasi di indonesia. Ini berarti bahwa jika terjadi perubahan persentase suku bunga naik sebesar 1 persen, maka perubahan tingkat inflasi di indonesia akan naik sebesar 1.678432 persen. Sedangkan dalam jangka panjang suku bunga mempunyai hubungan yang positif dan signifikan terhadap tingkat inflasi Indonesia. Ini berarti bahwa jika suku bunga naik sebesar 1 persen, maka tingkat inflasi di Indonesia akan naik sebesar 1.678432 persen.

Pengaruh perubahan kurs terhadap perubahan tingkat inflasi di indonesia Dari hasil perhitungan menunjukkan bahwa perubahan persentase kurs dalam jangka pendek (D(log)kurs)) mempunyai hubungan yang positif dan signifikan terhadap perubahan persentase Tingkat inflasi di indonesia. Hal ini sesuai dengan teori, bahwa semakin tinggi tingkat kurs maka akan menaikan tingkat Inflasi di Indonesia. Jika terjadi perubahan persentase kurs naik sebesar 1 persen, maka perubahan tingkat inflasi di Indonesia akan naik sebesar 0.003727 persen. Sedangkan dalam jangka panjang kurs mempunyai hubungan yang positif dan signifikan terhadap tingkat inflasi di Indonesia. Jika terjadi perubahan persentase kurs naik sebesar 1 persen, maka perubahan tingkat inflasi di Indonesia akan naik sebesar 0.003727 persen.

\section{Implikasi}

Koefisien parameter variabel suku bunga memiliki tanda koefisien yang positif sebesar 1.678432, berarti setiap ada kenaikan variabel suku bunga sebesar $1 \%$ maka akan meningkatkan variabel inflasi sebesar $1.67 \%$ dengan anggapan faktor lainnya konstan. Dengan demikian perhitungan ini telah sejalan dengan hipotesis yang menyatakan bahwa suku bunga berpengaruh positif terhadap inflasi. Semakin tinggi tingkat bunga maka semakin tinggi tingkat inflasi, atau sebaliknya. Sejalan dengan teori efek Fisher, bahwa ada hubungan satu untuk satu antara inflasi dan tingkat bunga. Disamping itu, karena tingkat bunga merupakan refleksi dari tingkat inflasi, maka ketika tingkat bunga tinggi maka akan 
mengurangi kegairahan penanam modal untuk mengembangkan sektor-sektor yang produktif.

Variabel nilai kurs merupakan salah satu variabel independent yang mempengaruhi variabel dependent, yaitu tingkat inflasi di indonesia. Nilai kurs merupakan harga atau nilai dari mata uang dari suatu negara terhadap mata uang negara yang lain. Hasil temuan menunjukkan bahwa dalam jangka pendek nilai kurs mempunyai pengaruh positif dan signifikan terhadap tingkat inflasi di indonesia. Begitu pun juga Dalam jangka panjang nilai kurs mempunyai pengaruh positif dan signifikan terhadap tingkat inflasi di indonesia. Hasil sejalan dengan dasar teoretik dan hipotesis bahwa semakin tinggi nilai kurs, maka tingkat inflasi akan semakin tinggi pula. Dengan kata lain tinggi rendahnya tingkat inflasi dipengaruhi oleh tinggi rendahnya nilai kurs yang di hasilkan oleh suatu negara.

\section{Kesimpulan}

Penelitian ini dimaksudkan untuk mengkaji pengaruh suku bunga, dan nilai kurs terhadap tingkat inflasi di Indonesia pada kurun waktu 1985 sampai 2014 dengan menggunakan ECM (Error Correction Model). Dari hasil analisis dan pembahasan yang telah dilakukan dapat diambil kesimpulan, suku bunga berpengaruh Positif dan signifikan terhadap tingkat inflasi di indonesia dan temuan ini sesuai dengan teori jika suku bunga meningkat maka tingkat inflasi di indonesia akan meningkat. Nilai kurs berpengaruh positif dan signifikan terhadap tingkat inflasi di indonesia dan temuan ini sesuai dengan teori yang menunjukkan bahwa jika nilai kurs rupiah terdepresiasi terhadap Us dollar, maka inflasi yang terjadi semakin naik. Dalam penelitian yang telah dilakukan nilai kurs mempunyai hubungan positif dengan tingkat Inflasi.

\section{Daftar Pustaka}

Atmadja S.A, Inflasi indonesia :Sumber sumber Penyebab Dan pengendaliannya Jurnal Akuntansi dan Keuangan Vol. 1 No. 1, Mei 1999 Universitas Kristen Petra.

Basuki, A.T, Yuliadi, Imamudin, Elektronic Data Processing (SPSS 15 dan EVIEWS 7), (Yogyakarta: Danisa Media, 2015).

Endri, "Analisis Faktor- Faktor Yang mempengaruhi Inflasi Jangka Pendek di Indonesia". Jurnal Ekonomi Pembangunan Kajian Negara Ekonomi Negara Berkembang, Hal: 1-13 2008.

Langi, Manuela, Theodores, et.al, Analisis Pengaruh Suku Bunga BI, Masinambow, Hanly Jumlah Uang Beredar, dan tingkat Kurs Terhadap Tingkat Inflasi Di Indonesia. Jurnal Berkala Ilmiah Efisiensi, Mei 2014, Volume 14 No.2.

Mankiw, N. Gregory, Pengantar Ekonomi Makro Edisi Asia Volume 2, Uakarta: Salemba Empat, 2013)

Rangkuti A.E, Faktor-Faktor Yang Mempengaruhi Permintaan Uang kartal Di Indonesia, (Medan: Universitas Sumatera, 2007).

Sukirno, Sadono, Pengantar Teori Makro Ekonomi Edisi Kedua, (Jakarta: PT Raja Grafindo Persada, 1999).

Triyono, "Analisis PerubahanKurs Rupiah Terhadap Dollar Amerika" Jurnal Ekonomi Pembangunan, Vol 9, No.2, Desember 2008, hal 156-167. 